\title{
Analysis of Capital Flight in Developing Countries: A Study on Turkey between 1980 and 2010
}

\author{
Asst. Prof. Dr. Ali Özer (Erzincan University, Turkey) \\ Ph.D. Candidate Aslı Cansin Doker (Erzincan University, Turkey) \\ Ph.D. Candidate Adem Türkmen (Erzincan University, Turkey)
}

\begin{abstract}
The aim of this study is to determine whether there is a relationship between Capital flight and some macroeconomic variables by using anual data between 1980 and 2010 in Turkey. Capital flight measured by World Bank (1985) method, was used as dependent variable and external debt, foreign direct investment, uncertainty, real GDP growth, exchange rates, trade balance and consumer price index were used as independent variables. Ordinary Least squares estimation method, Johansen-Jeselius cointegration test, Granger causality test and variance decomposition results produced by VEC model were used in the study. After those econometrics and economics analysis, this paper put forward that there is a long run relationship between some macroeconomic variables and capital flight.The results show external debt, foreign direct investment inflows, and foreign reserves to be the major effector of capital flight.
\end{abstract}

\section{Introduction}

It is suggested to developing countries opening the capital outside for attract capital and finance their investment. These countries adapted to financial liberalazation policies and benefited from large amounts of capital input in accordance with these recommandations. Dependency on foreign capital is generally quite variable and exhibits an unstable structure, has made these countries more vulnerable to the financial crisis. The specified point, has affected developing countiries, including Turkey. These developments have led to discussions about importance capital flight in Turkey and how we could be back this capital from abroad.

There is no generally accepted definition of capital flight, even though its activities have been identified for periods dating back to the seventeenth century.The variety of capital flight definitions (Cuddington 1986; World Bank 1985; Morgan Guaranty Trust Company 1986; Cline 1987; Dooley 1986; Lessard and Williamson 1987) makes it diffucult to separate normal capital out flows and flight capital out flows. Although there is no generally accepted definition of capital flight, the literature has postulated three major reasons for its existence: (1) investment, (2) money laundering, and/or (3) tax evasion (Boyrie 2010).

Although capital flight has been a problem as early as the seventeenth century in Europe and in the early twentieth century in Europe and United States of America (see, e.g., Kindleberger, 1987), the subject matter in the contemporary world latter gained momentum again since the early 1980 s.

Demirgil (2011) examined capital flight and instability for Turkey between 1970 and 2006 with using GARCH and EGARCH analysis and he founded that political instability affects on economic growth negatively and on inflation rate positively, additionally exchange rate does not have long run and strong effect on macroeconomic varibles.(Demirgil H., 2011)

\section{Literature}

There are many of studies and research papers examined the reasons and results/impacts of capital flight in developing countries. Most of them investigated relationship between macroeconomics variables, which can be classified such as foreign direct or indirect investment, infilation, external debt, and capital flights. In addition, there are many of studies related to measurement of capital flight. In this section, those indicators and findings will be discussed in respect of determinants of capital flights, measurements for capital flights and classification diffrences for analysing capital flight.

Ndikumana and Boyce (2003) examined with their seminar paper which way the relationship between capital flight and external borrowing has in African countries between 1970 and 1996. One of important result of their study is that external borrowing effects significant and positively to capital flight. Another important finding from their study is related to persistence of the value of capital flight which was found significant. This result shows that past data of capital flight can cause or effect future data of capital flight.

The impacts of capital flight in Indonesia, Malaysia and Thailand were examined with using the explanation of revolving door mechanism by Beja (2007). He put forward three type of risk as causes or explanaories of capital flights. Moreover, there are very importance finding from this paper such that large capital flows follow revoling door mechanism. This study also shows lost capital in these countries may well return as either foreign investment or debt hence following revolving door mechanism. One of econometric result of this paper is capital flight causes debt and high level of risk. From conclusion of this paper is an adequate amount of international 
reserves and trustworthy indicator of economic growth could well cause decrease of external borrowing and capital flight.

About explation power of external borrowing for capital flight in China is analysed by Ljuingwall and Wall (2008). In their study, balance of payment data between 1993 and 2003 is used. In china external borrowing is significant, in other words external borrowing can be an explanation for capital flights. Another supportive study related to China is about external borrowing fuels findings are similar to Latin America except interest rate and exchange rate significancy which China does not have those indicators. Frank R. Gunter (2003) presented that capital policies in China between 1998 and 1999 did not change level of capital flights with using balance of payment and residuals measurements.

Another important research of capital flight with using portfilo choice model was conducted by Quan Vu Le and Paul J. Zak (2006). The inflences from this paper can be written such that firstly, the political stability is the most crucial factor to return capital flights. Secondly, with using three types of risk, which economic risk, political instability, and policy variability are, explains capital flights statistically significant. In 2011, Yasemin Yalta and A. Talha Yalta examined effects of financial liberalisation on magnitude of capital flight with using panel causality modelling in private sector. Their sample was 21 emerging market economies between 1980 and 2004 time period. This study showed that there is no significant proof of causal relationship and their result is that financial liberalasation could not be useful for reducing capital flight. Furhtermore, Maria E. de Boyrie (2010) examined determinants of capital flight and capital movement through trade missing including African Case between 1990 and 2005. In this study, 21 independent variables were used as a result of this capital flight could not explain all capital flows. Moreover, long-term relationship was found only for a few cases. They also concluded their paper with recommendation for African policymakers such as putting forward stronger and more specified trade policies to decrease capital flight. There is also another paper which is conducted for investigating the causes of capital flight on Zimbabwe between 1980 and 2005. (Makochekanwa A., 2007)

In econometrics aspect, capital flight is subject with several techniques which are causality, cointegration, panel analysis and unit root and simultaneous equations. For instance, Chipakatti and Rishi (2002), they applied utilized simitaneous equations to associate external debt and capital flight in Indian case during 1971-1997 and the study confirmed that this relationship is following same way with revolving door mechanism. Another econometric method was used for capital flight research is coingtegrtion technique which is developed by Pesaran et.al.(2001). The findings from this paper states that income taxes, higher real interest rate diffrentials are significant to identify capital flight. As a result of this findings and research political stability is the most effective factor to prevent from capital flight.(Alam, M, Quazi R., 2003)

\section{Capital Flight Measurement}

There is no concensus measure of capital flight. There are several methods used in the literature to measure capital flight. Some of them are direct, while others are indirect. The Residual measure introduced by the World Bank (1985) is the most popular measure and it relies on the indirect definition of capital flight. The World Bank (1985) estimates the capital flight as the difference between the sources of funds and uses of funds. According to World Bank definition, capital flight can be written as follows:

$$
\mathrm{CFR}=\mathrm{CXB}+\mathrm{NFDI}-\mathrm{CAD}-\mathrm{COF}
$$

Where:

$\mathrm{CFR}=$ Capital Flight (residual measure)

$\mathrm{CXB}=$ Change in external borrowing

NFDI $=$ Net foreign direct investment

$\mathrm{CAD}=$ Current account deficit

COFR $=$ Change in official foreign reserves

Dooley (1986) method distinguished between normal capital flows from abnormal capital flows. Based on this approach, the motive behind capital flight is the individual assumptions about the individuals' motives. Capital flight is therefore measured as the sum of externally held assets of the private sector that does not generate recorded income in the Country's balance of payments. Following Hermes et al $(2002$, p.2), the Dooley method of measuring capital flight can be derived as follows:

$\mathrm{TCO}=\mathrm{FB}+\mathrm{FDI}-\mathrm{CAD}-\Delta \mathrm{FR}-\mathrm{EO}-\Delta \mathrm{WBIMF}$

Where;

TCO is total capital outflows,

FB is foreign borrowing as reported in the balance of payments,

FDI is the net foreign investment inflows,

FR is the stock of official foreign reserves, 
CAD is the current account deficit/surplus,

EO is net errors and omissions (debit entry),

WBIMF is the difference between the change in the stock of external debt and foreign borrowing reported in the balance of payments

Another indirect measure introduced by Morgan Guaranty Trust Company (1986),

$$
\mathrm{CFPC}=\mathrm{CXB}+\mathrm{NFDI}-\mathrm{CAD}-\mathrm{COFR}-\mathrm{CBSFA}
$$

Where,

CFPC $=$ Capital flight (private claim)

CBSFA $=$ Change in short - term banking system foreign assets

The balance of payments measure introduced by Cudington (1986) defines capital flight as short-term capital outflow rather than total outflow of capital by the private sector. Cuddington measure can be calculated as follows:

$\mathrm{CFC}=\mathrm{NBSC}+\mathrm{EO}$

Where,

$\mathrm{CFC}=$ Capital flight (Cuddington)

NBSC $=$ Non-bank short-term capital outflow

$\mathrm{EO}=$ Balance of payments errors and omissions

Ajilore (2010) argues that countries that have strong capital flight proclivities, it is reasonable to assume that trade mis-invoicing may be utilized as a channel for capital flight. Trade mis-invoicing method equations are given as follow:

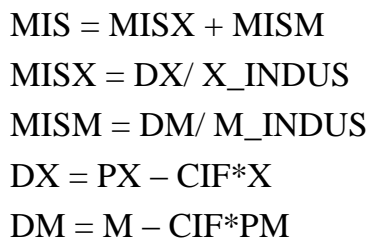

Where;

MIS = total trade mis-invoicing

MISX $=$ trade mis-invoicing from the export

MISM $=$ trade mis-invoicing from the import

$\mathrm{DX}=$ total export discrepancies with trade partners

$\mathrm{DM}=$ total import discrepancies with trade partners

X_INDUS = industrialized-country trading-partners in the country's total import

M_INDUS = industrialized-country trading-partners in the country's total export

$\mathrm{PX}=$ trading partner's import value

$\mathrm{PM}=$ trading partner's export value

$\mathrm{M}=$ reported imports

$\mathrm{X}=$ reported exports

$\mathrm{CIF}=$ cost of freight and insurance adjustment

\section{Methodology}

The theory does not offer a sharp way of determining a priori which independent variables should be included when we examine that factors that affect the variation in the capital flight. Therefore, we follow the literature and examine the most important variables that have been considered.

The following model is employed in the analysis of the determinants of capital flight in Turkey;

$\mathrm{CF}=\alpha_{0}++\alpha_{1} \mathrm{ED}+\alpha_{2} \mathrm{INF}+\alpha_{3} \mathrm{FDI}+\alpha_{4} \mathrm{ER}+\alpha_{5} \mathrm{UNC}+\alpha_{6} \mathrm{TBAL}+\alpha_{7} \mathrm{GR}+\varepsilon_{\mathrm{t}}$

Where,

Capital Flight (CF): We use the World Bank (1985) method .

External Debt (ED): is measured as change in external debt divided by GDP. A positive relationship between the external debt and capital flight is expected

Inflation (INF): is the rate of inflation in the domestic economy. We measure inflation as consumer price index. 
Foreign Direct Investment (FDI): We include this variable in the model in order to see if FDI facilitate or reduce capital flight (see Le and Rishi, 2006)

Exchange Rate (ER): is the yearly average of exchange rate of one US dollar in Turkey.

Uncertainty (UNC): We measure the macroeconomic uncertainty by calculating the deviation of GDP from its three-year moving average.

Trade Balance (TBAL): is the trade balance in million US dollars.

Real GDP Growth (GR): Following Mikkelsen (1991), we use Real GDP growth rate as a measure for real rate of return of the economy. The higher the level of growth in the economy and hence the opportunities for domestic investments, the less the incentives to engage in capital flight. (Ajayi 1992) A negative relationship is expected between capital flight and Real GDP.

$\varepsilon_{\mathrm{t}}$ is the error term.

In the study, determinant of capital flight is investigated with both ordinary least squares and a Vector Error Correction model for mutual relationship between these variables. VEC model is introduced by Engle and Granger (1987) for examining cointegration i.e. for long-run relationship between variables in Vector Autoregression (VAR) model. A VEC model can be expressed as follow.

$$
\Delta \mathrm{x}_{\mathrm{t}}=\alpha+\mathrm{B}(\mathrm{L}) \Delta \mathrm{x}_{\mathrm{t}-1}+\mathrm{d}^{\prime}\left(\mathrm{e}_{\mathrm{t}-1}\right)+\mathrm{y}_{\mathrm{t}}
$$

Where;

$$
\begin{aligned}
& \Delta \mathrm{x}_{\mathrm{t}}=\mathrm{n} \times \mathrm{t} \text { vectors of variables, } \\
& \alpha=\mathrm{n} \times 1 \text { vectors of constants, } \\
& \mathrm{B}(\mathrm{L})=\mathrm{n} \times \mathrm{n} \text { matrices of the polynomial expression in the lag operator, } \\
& \mathrm{d}^{\prime}=\mathrm{n} \times 1 \text { vectors of constants, } \\
& \mathrm{e}_{\mathrm{t}-1}=\mathrm{n} \times \mathrm{t} \text { vectors of error correction terms, } \\
& \mathrm{y}_{\mathrm{t}}=\mathrm{n} \times \mathrm{t} \text { vectors of residuals. }
\end{aligned}
$$

In the study, Granger causality test is applied for investigating direction of relationship between variables. This test is fist applied in the literature by Granger (1969). Then, Hamilton (1994) developed this test. In Granger causality, the direction of relationship is investigated between variables like $\mathrm{x}$ and $\mathrm{y}$. If the current $\mathrm{y}$ value is better estimated with past values of $x$ rather than current value of $x$, we can say that there is Granger causality from $\mathrm{x}$ to $\mathrm{y}$ variable.

The data employed in this study are yearly macroeconomic variables which include, capital flight, interest rate, inflation, external debt stock, exchange rate, foreign direct investment, trade balance, uncertainity and real GDP growth. The sample period is from 1980 through 2010. All data were directly obtained from CBRT (Central Bank of the Republic of Turkey) Electronic Data Delivery System, International Financial Statistics (IFS) issued by International Monetary Fund and World Bank Data. Eviews 7.1 was used for analysis.

\section{Empirical Analysis and Discussion}

The regression of a nonstationary time series on another nonstationary time series may produce a spurious regression. In order to produce a meaningful estimate, it is important to conduct a unit root test. Testing for the existence of unit roots is a principal concern in the study of time series models and co-integration. The presence of a unit root implies that the time series under investigation is non-stationary; while the absence of a unit root shows that the stochastic process is stationary. The Augumented Dickey-Fuller test as presented in Dickey and Fuller (1979) is an important tool for doing this. To test the null hypothesis of a unit root, the t-statistic and the asymptotic critical values were taken from Davidson and MacKinnon (1993). This outcome is presented in Table 1.

\begin{tabular}{|l|l|l|l|}
\hline Variables & Levels & First Difference & Second Difference \\
\hline CF $(0)$ & -2.493982 & $-4.757862^{*}$ & - \\
\hline ED $(0)$ & -2.582605 & $-4.083576^{* *}$ & - \\
\hline INF (1) & -2.564259 & $-4.334224^{*}$ & - \\
\hline FDI (1) & -1.974891 & $-7.354670^{*}$ & - \\
\hline ER (0) & $-5.880260^{*}$ & - & - \\
\hline UNC (2) & -1.595645 & $-12.13160^{*}$ & - \\
\hline TBAL $(0)$ & $-4.498936^{*}$ & - & - \\
\hline GR (3) & -3.149052 & -2.439746 & $-4.145467^{* *}$ \\
\hline
\end{tabular}

Table 1: Result of Stationary Test (Augmented Dickey-Fuller Test) (Note: * significant at 10\%; ** significant at $5 \%$;** significant at $1 \%$ ) 
The table above shows that the stationarity of the variables at different levels of differencing. It could be seen that ER and TBAL are the variables that is stationary at level difference while other variables are stationary at first difference except GR which is stationary at second difference. Below is the presentation of the least square estimation results from the analysis conducted on the model.

\begin{tabular}{|l|l|l|}
\hline Variables & Coefficient & T-Statistic \\
\hline C & 47.42254 & $8.344144^{*}$ \\
\hline ED & 0.00914 & $19.63005^{*}$ \\
\hline INF & -0.163405 & -1.605811 \\
\hline FDI & -0.001770 & $-1.971529^{* * *}$ \\
\hline ER & -27.14612 & $-5.689021^{*}$ \\
\hline GR & $-2.51 \mathrm{E}-08$ & $-0.833179^{*}$ \\
\hline UNC & $1.18 \mathrm{E}-07$ & $1.065974^{*}$ \\
\hline TBAL & 0.002213 & $2.665611^{* *}$ \\
\hline \multicolumn{2}{l}{} \\
\hline $\mathrm{R}^{2}$ & 0.9265 & \\
\hline DW & 1.9361 & \\
\hline F & $124.6686^{*}$ & \\
\hline
\end{tabular}

Table 2: The Least Square Estimation Results (* significant at 10\%; ** significant at 5\%; *** significant at 1\%)

According to regression model we use, the results for independent variables, except INF all the variables are significant which means that only inflation rate has no influence on the capital flight in Turkey during the study period. From the above results, it can be seen that the co-efficient of the constant parameter is positively related with the CF. This indicates that if all explanatory variables are held constant, CF will increase by 47.42254 units. The explanatory power of the model is estimated at 0.9265 which indicates that $92.65 \%$ variations or changes that occurs in the present state of CF is determined by the changes in the values of the independent variables while the remaining $7.35 \%$ is explained by the variation outside the model or captured by the error term. The Ftest statistic of 124.66 , significant at $1 \%$ indicates that conducted model is valid.

The coefficient UNC variable is positive and significant at the $1 \%$ level. Finding from analysis of relationship between uncertainty and capital flight is found positive and significant within 1 per cent level. In other words, uncertainty causes capital flight at per cent significance level. The content and the movement of recent and future public policies are indetermined and also it could well. Economic uncertainty is directly related to increase capital flight because of the characteristic of capital flight. From the theory, it is possible to say, if the economy has high level of uncertainty with using percentage of difference from previous value, this could be magnitude for capital flight. It is clear that policymakers should draw the way of the economy to prevent uncertainty level and relatively capital flight.

The results also indicate that the GR is negatively related to capital flight: higher growth leads to less capital flight. GDP growth rate is statistically significant at the 5\% level. Countries unable to improve economic growth, because of weak macroeconomic policies or inefficient economic sectors, will discourage investors.

The impact of the ED on CF is positive and significant at the $1 \%$ level. In economic theory, one of important indicator for economic instability can be external debt. In this situation, it is had to estimate the position of debtor credit and also it can struggle to use taxes as a preventer for decreasing external debt. As expected from the theory, there is significant and positive relationship between external debt and capital flight at $1 \%$ level.

The impact of the FDI on CF is negative and significant at the $10 \%$ level. Foreign direct investment has sensitivity to economic stability; of course, the econometric results are negative and significant relationship at $1 \%$ level. The meaning of this relationship is to put forward the policies for attracting foreign direct investment can reduce capital flight.

The impact of the TBAL on CF is positive and significant at the 5\% level. The impact of the trade balance is examined and relationship with capital flight is found significant and positive at $\% 5$ level. Increase in trade blance provides boost on exchange for the chosen county in other words the chosen country reaches the exchange surplus position. Consequently, this situation is resulted being exchange deficit position for another county. Based on that information, the foreign county aims to increase their investment rate for eliminating the exchange deficit position as a result of it, capital flight occurs.

The impact of the ER on CF is negative and significant at the $1 \%$ level. Another result from econometric analysis is related to exchange rate and capital flight which is found significant and negative with in $1 \%$. Decrease in exchange rates as a result of foreign portfolio investors who invested in hot money in TL, TL increases in the value of assets denominated in foreign currencies. Wishing to benefit from the increase in the return on the exchange rate difference arising out of the interest of foreign investors, capital flight occurs. Moreover, the decrease in exchange rates of foreign currencies appreciated the owners of capital market orientation shifts towards developing countries. 
There are various approaches to test for cointegration, say, Engle and Granger approach, Johansen approach and Gregory and Hansen approach. The bivariate approach of Engle and Granger is very restrictive because it can be applied only if there is one cointegrating relation. And the most commonly used method is the Johansen cointegration test based on the autoregressive representation discussed by Johansen (1988) and Johansen and Juselius (1990). This test determines the number of cointegrating equations for any normalization used. It provides two different likelihood ratio tests; one is based on the trace statistic and the other on the maximum eigenvalue. At this stage of the study, whether it is a long run relationship between the variables JohansenJuselius cointegration test is investigated. In addition, the Johansen-Juselius cointegration test of bilateral relations with $\mathrm{CF}$ was investigated.

\begin{tabular}{|l|l|l|l|l|l|l|l|l|}
\hline & \multicolumn{9}{|l|}{ Trace Test } & \multicolumn{2}{l|}{ Max-Eigen Test } \\
\hline & $\mathbf{H}_{\mathbf{0}}$ & $\mathbf{H}_{\mathbf{1}}$ & $\begin{array}{l}\text { Trace } \\
\text { Statistic }\end{array}$ & $\begin{array}{l}\mathbf{0 . 0 5 C r i t i c a l} \\
\text { Value }\end{array}$ & $\mathbf{H}_{\mathbf{0}}$ & $\mathbf{H}_{\mathbf{1}}$ & $\begin{array}{l}\text { Max-Eigen } \\
\text { Statistic }\end{array}$ & $\begin{array}{l}\text { 0.05Critical } \\
\text { Value }\end{array}$ \\
\hline None* $^{*}$ & $\mathrm{r}=0$ & $\mathrm{r} \geq 1$ & $388.7022^{*}$ & 187.4701 & $\mathrm{r}=0$ & $\mathrm{r}=1$ & $121.3865^{*}$ & 56.70519 \\
\hline At most 1* & $\mathrm{r}=1$ & $\mathrm{r} \geq 2$ & $267.3157^{*}$ & 150.5585 & $\mathrm{r} \leq 1$ & $\mathrm{r}=2$ & $87.17834^{*}$ & 50.59985 \\
\hline At most 2* & $\mathrm{r}=2$ & $\mathrm{r} \geq 3$ & $180.1374^{*}$ & 117.7082 & $\mathrm{r} \leq 2$ & $\mathrm{r}=3$ & $62.58674^{*}$ & 44.49720 \\
\hline At most 3* & $\mathrm{r}=3$ & $\mathrm{r} \geq 4$ & $117.5506^{*}$ & 88.80380 & $\mathrm{r} \leq 3$ & $\mathrm{r}=4$ & $52.23570^{*}$ & 38.33101 \\
\hline At most 4 & $\mathrm{r}=4$ & $\mathrm{r} \geq 5$ & 62.31494 & 63.87610 & $\mathrm{r} \leq 4$ & $\mathrm{r}=5$ & 25.86353 & 32.11832 \\
\hline At most 5 & $\mathrm{r}=5$ & $\mathrm{r} \geq 6$ & 39.45141 & 42.91525 & $\mathrm{r} \leq 5$ & $\mathrm{r}=6$ & 20.19299 & 25.82321 \\
\hline At most 6 & $\mathrm{r}=6$ & $\mathrm{r} \geq 7$ & 19.25842 & 25.87211 & $\mathrm{r} \leq 6$ & $\mathrm{r}=7$ & 13.32489 & 19.38704 \\
\hline At most 7 & $\mathrm{r}=7$ & $\mathrm{r} \geq 8$ & 5.933532 & 12.51798 & $\mathrm{r} \leq 7$ & $\mathrm{r}=8$ & 5.933532 & 12.51798 \\
\hline
\end{tabular}

Table 3. Johansen Cointegration Test Results (Multivariate)

In Table 3, cointegration of variables expressing whether the hypothesis $\mathrm{H}_{0}(\mathrm{r}=0)$ of the Trace Statistic is calculated 388.7022. This value is obtained from the 5\% significance level, the null hypothesis was rejected because it is larger than the critical value of 187.4701 and cointegrated vector have been identified. Both statistic tests which are Trace and Max-Eigen statistic produced similar results. Either the trace test or the maximum eigenvalue test reveals the presence of a cointegrating vector, implying that there is a long-run equilibrium relationship between the variables. The results show that there is more than one cointegrating vectors whereby there are four cointegrating vectors between the CF and other variables. This gives the conclusion that in the long-term CF moves together with other variables towards equilibrium. In this context about the relationship between long-term stability can be mentioned and cointegration vector estimates obtained from this relationship is shown below.

$$
\mathrm{CF}=-0.001103 \mathrm{ED}+0.324888 \mathrm{INF}+0.005969 \mathrm{FDI}+24.83708 \mathrm{ER}+-1.12 \mathrm{E}-07 \mathrm{GR}
$$
(2.7E-05)
(0.16277)
(0.00048)
(2.77017)
(4.9E-08)

-1.12E-06 UNC-0.003491DTD

\section{(1.5E-07) (0.00089)}

(Note: An estimate of the cointegration vector is normalized according to CF. Standard error in parentheses.)

In this study, we are not discuss more on the interpretation of these number of cointegrating vectors due to the problems of interpretation when dealing more than one cointegrating vector (see Maddala and Kim, 1998: 233242).

\begin{tabular}{|l|l|l|l|l|c|}
\hline & $\mathrm{H}_{0}$ & $\mathrm{H}_{1}$ & Trace Statistic & $\mathbf{0 . 0 5}$ Critical Value & 0.01Critical Value \\
\hline CF-ED & $\mathrm{r}=0$ & $\mathrm{r}=1$ & 16.67821 & 18.39771 & 23.15239 \\
& $\mathrm{r} \leq 1$ & $\mathrm{r}=2$ & $5.966755^{* *}$ & 3.841466 & 6.634897 \\
\hline CF-FDI & $\mathrm{r}=0$ & $\mathrm{r}=1$ & 16.17171 & 18.39771 & 23.15239 \\
& $\mathrm{r} \leq 1$ & $\mathrm{r}=2$ & 2.683073 & 3.841466 & 6.634897 \\
\hline CF-ER & $\mathrm{r}=0$ & $\mathrm{r}=1$ & 14.58948 & 18.39771 & 23.15239 \\
& $\mathrm{r} \leq 1$ & $\mathrm{r}=2$ & $6.163261^{*} *$ & 3.841466 & 6.634897 \\
\hline CF-GR & $\mathrm{r}=0$ & $\mathrm{r}=1$ & $43.74255^{*}$ & 18.39771 & 23.15239 \\
& $\mathrm{r} \leq 1$ & $\mathrm{r}=2$ & 3.348945 & 3.841466 & 6.634897 \\
\hline CF-INF & $\mathrm{r}=0$ & $\mathrm{r}=1$ & 12.65611 & 18.39771 & 23.15239 \\
& $\mathrm{r} \leq 1$ & $\mathrm{r}=2$ & $4.684800^{* *}$ & 3.841466 & 6.634897 \\
\hline CF-UNC & $\mathrm{r}=0$ & $\mathrm{r}=1$ & $48.80179^{*}$ & 18.39771 & 23.15239 \\
& $\mathrm{r} \leq 1$ & $\mathrm{r}=2$ & $6.269029^{* *}$ & 3.841466 & 6.634897 \\
\hline CF-TBAL & $\mathrm{r}=0$ & $\mathrm{r}=1$ & 13.63300 & 18.39771 & 23.15239 \\
& $\mathrm{r} \leq 1$ & $\mathrm{r}=2$ & 2.256511 & 3.841466 & 6.634897 \\
\hline
\end{tabular}

Table 4. Bivariate Johansen's Cointegration Test Results (Note: * significant at 1\%; ** significant at 5\%) 
According to the bivariate cointegration test presented in Table 4, while there is a cointegration relationship between CF and ED, ER, GR, INF and UNC variables, a cointegration relationship can not be observed between $\mathrm{CF}$ and FDI, and TBAL. So, we can say that there is a long run relationship between CF and ED, ER, GR, INF and UNC variables.

It's already known that cointegration implies the existence of Granger causality, but it does not indicate the direction of the causality relationship. So, at least one directional relationship must be expected between variables. Table 5 presents Granger causality test results between CF and the other variables from VEC model.

\begin{tabular}{|l|l|l|l|}
\hline Variables & Direction of Causality & F Statistics & Probability \\
\hline CF-ED & $\rightarrow$ & $2.77274^{* * *}$ & 0.0762 \\
ED-CF & - & 1.90672 & 0.1637 \\
\hline CF-FDI & - & 1.12469 & 0.3362 \\
FDI-CF & - & 1.20145 & 0.3129 \\
\hline CF-ER & - & 0.18041 & 0.8357 \\
ER-CF & - & 2.26982 & 0.1183 \\
\hline CF-GR & $\rightarrow$ & $4.32697^{*}$ & 0.0041 \\
GR-CF & $\rightarrow$ & $11.67002^{*}$ & 0.0000 \\
\hline CF-INF & - & 2.11194 & 0.1362 \\
INF-CF & - & 0.19736 & 0.8218 \\
\hline CF-UNC & - & 0.38232 & 0.6851 \\
UNC-CF & $\rightarrow$ & $10.3067 *$ & 0.0003 \\
\hline CF-TBAL & - & 0.63606 & 0.5354 \\
TBAL-CF & $\rightarrow$ & $3.21583^{* * *}$ & 0.0522 \\
\hline
\end{tabular}

Table 5: Granger Causality Test Results from VECM (Note: * significant at 10\%; ** significant at 5\%; *** significant at 1\%)

According to the test results, there is a bidirectional causality between CF and GR. Also, we found causality from changes in UNC and TBAL to changes in CF. This means uncertainty and trade balance anticipate changes in capital flight and capital flight appear to have no effect on uncertainty and trade balance. There is no causality between $\mathrm{CF}$ and FDI, ER and INF variables.

The variance decomposition measures the proportion of forecast error variance in one variable explained by innovations in itself and the other variables. The results are summarized in Table 6 . The salient results from the variance decomposition technique are as follows: in general, own shock constitutes the predominant source of variations for all the variables in the model. Variance decomposition results from VEC model are given in Table 6.

\begin{tabular}{|l|l|l|l|l|l|l|l|l|}
\hline Periods & CF & ED & INF & FDI & ER & GR & UNC & TBAL \\
\hline 1 & 100.000 & 0.00000 & 0.00000 & 0.00000 & 0.00000 & 0.00000 & 0.00000 & 0.00000 \\
\hline 2 & 85.3166 & 0.82238 & 0.06690 & 0.59299 & 0.98027 & 5.29727 & 0.03896 & 6.88459 \\
\hline 3 & 74.7235 & 1.15919 & 0.05147 & 0.55518 & 1.00143 & 4.79465 & 0.89311 & 16.8213 \\
\hline 4 & 67.3776 & 1.41054 & 0.10891 & 0.60066 & 1.27914 & 3.67521 & 2.89336 & 22.6544 \\
\hline 5 & 62.8371 & 1.53081 & 0.26416 & 1.22525 & 2.33019 & 3.46534 & 4.13864 & 24.2084 \\
\hline 10 & 47.4866 & 4.81941 & 3.65416 & 2.17016 & 2.40722 & 2.96976 & 7.05528 & 29.4373 \\
\hline 15 & 22.2175 & 4.69556 & 13.4248 & 4.45967 & 1.28795 & 10.1928 & 11.0337 & 32.6877 \\
\hline 20 & 18.1492 & 4.19453 & 15.4465 & 4.87064 & 1.00009 & 11.5683 & 11.5719 & 33.1986 \\
\hline 25 & 14.4481 & 3.71537 & 17.5413 & 5.40874 & 0.77755 & 12.8466 & 12.0876 & 33.1746 \\
\hline 30 & 11.2494 & 3.33624 & 19.4385 & 5.86550 & 0.59273 & 14.4343 & 12.4551 & 32.6280 \\
\hline
\end{tabular}

Table 6. Variance Decomposition

According to the variance decomposition results, CF variable is mostly affected by its shocks, and then by variables of trade balance, inflation rate, growth, uncertainty, foreign direct investment, external debt, and exchange rate, respectively. At the beginning of the period, capital flight is determined only by their shocks but at the end of the 30 years, this ratio decreases to $11,2 \%$. So, $88,8 \%$ percentage of change in CF was determined by variables used in the study. Trade balance shows its impact after the fourth year and this ratio rises to $32 \%$ at the end of the period. Inflation affects CF by 2,8\% at the end of the fourth year and this ratio rises to $19 \%$ at the end of the 30th year. The effect of ER is rather small.

\section{Conclusion}

Recently capital flight has been became one of important issue for the developing countries'government and the main question is how it can be measured in orther words which measurement can show real capital flight 
effect on macroeconomic variables. After the financial crisis, develeoping countiries affected mostly including Turkey. Turkish government has been trying to fing a way to get back the capital from abroad. The chosed medhod to calculate capital flight is the residuals method which is used by World Bank. The aim of this study is to investigate the relationship between capital flight and some macroeconomic variables which are GDP per capita, exchange rate direct financial investment, rate of inflation and trade balance. For this aim, OLS method, Johansen- Juselius cointegration method, Granger causality test and VEC model are used. OLS estimation results show that there are significant relationships between capital flight and exchange rate, trade balance, exchange rate, uncertainty, financial direct investment and external debt. However, rate of infilation is insignificant with $10 \%$. There are positive impacts on trade balance, uncertainty and external debt as expected from the economics theory. Additionally, there are negative relationshiops between capital flight and financial direct investment and exchange rate. It is recommended that policymaker should put forward stricted laws to prevent capital flight; this paper shows that capital flight can be a cause of macroeconomic instability and vice verca.

\section{References}

- Ahmed A. (2013). Effects of financial liberalization on financial market development and economic performance of the SSA region: An empirical assessment. Economic Modelling, 30,261-273.

- Ajilore, O.T. (2010). “An Economic Analysis of Capital Flight from Nigeria”, International Journal of Economics and Finance, 2 (4), pp.89-101.

- $\quad$ Alam, M, Quazi R (2003). "Determinants of Capital Flight: An Econometric Case Study Of Bangladesh", International Review of Applied Economics, 17, pp.85-103.

- Beja, E (2007). "Brothers in Distress: Revolving Capital Flows of Indonesia, Malaysia, and Thailand", Journal of Asian Economics, 18, pp.904-914.

- Beja, Jr. L .Edsel. (2006). "Revisiting the Revolving Door: Capital Flight from Southeast Asia”, DESA Working Paper No. 16.ST/ESA/2006/DWP/16.

- $\quad$ Boratav,K. et.al, 1996. Dilemmas of Structural Adjustment and Environmental Policies Under Instability: Post-1980 Turkey .World Development,Volume 24, Issue 2, February 1996, Pages 373-393.

- Boyrie M., (2010). "Determinants of Capital Flight and Capital Movement through Trade Misspricing The African Case", Afican Journal of Accounting Economics, Finance and Banking Research, Vol.6 No.6.

- $\quad$ Boyrie, Maria E., (2010). "Determinants of Capital Flight and Capital Movement Through Trade Mispricing: The African Case", African Journal of Accounting, Economics, Finance and Banking Research, 6(6), pp.1-16.

- Broner F. et al, (2013). "Cross Capital Flows: Dynamics and Crisis”, Journal of Monetary Economics, 60, pp.113-133.

- Chipalkatti, N. and M. Rishi. (2001). "External Debt and Capital Flight in the Indian Economy", Oxford Development Studies, 29(1).

- Cuddington, J T (1986). “Capital Flight: Issues and Explanations”, Princeton Studies in International Finance, 58, Princeton, NJ: Princeton University.

- Davidson, R., \& MacKinnon, J. G. (1993), Estimation of Inference in Econometrics. Oxford University Press.

- Demir, F. (2004).A Failure Story: Politics and Financial Liberalization in Turkey, Revisiting the Revolving Door Hypothesis. World Development Vol. 32, No. 5, pp. 851-869, 2004.

- Demirgil, H. 2011. Political Instability, Uncertainty and Macroeconomics: the Case of Turkey (19702006). Marmara Üniversitesi I.I..B.F. Dergisi, vol 31, issue 2, pp. 123-144.

- Dickey, D. A., \& Fuller, W.A. (1979). Distribution of the Estimators for Autoregressive Time Series with a Unit Root. Journal of the American Statistical Association, 74, 427-437.

- Engle, R. E., C. W. J. Granger, “Cointegration and Error Correction: Representation, Estimation, and Testing”, Econometrica, 55, 1987, pp: 251-276.

- Epstein G. A.,2005. Capital Flight and Capital Controls in Develeoping Countries. Edwad Edgar Publishing, Cheltenham,UK.

- $\quad$ Gunter, F.R.,(2004). Capital Flight from China 1984-2001.China Economic Review, 15, pp: 63-85.

- Johansen, S., (1988). "Statistical Analysis of Cointegration Vectors", Journal of Economic Dynamics and Control, 12, pp.231-254. 
- Johansen, S., Juselius, K., (1990). "Maximum Likelihood Estimation and Inference On Cointegration With Applications to The Demand For Money", Oxford Bulletin of Economics and Statistics, 52, pp.169-209.

- Kindleberger, C. P. (1987). “A Historical Perspective,' in D. R. Lessard, and J. Williamson (eds), Capital Flight and Third World Debt. Washington, DC: Institute for International Economics, pp.7-26.

- Ljungwall C and Wang Z (2008). "Why is capital flowing out of China?”, China Economic Review, 19, pp.359-372.

- Maddala, G.S. and Kim, I-M., (1998). “Unit Roots, Cointegration, And Structural Change”, Cambridge: Cambridge University Press.

- Makochekanwa, A. (2007). “An Empirical Investigation of Capital Flight from Zimbabwe”, Department of Economics University of Pretoria Working Paper Series 2007-11.

- Morgan Guaranty Trust Company (1986). "LDC Capital Flight”, World Financial Markets (March), pp.13-15.

- Ndikumana L. and Boyce J.(2003). Capital Flight from North-Africa Countries. Massachusetts: University of Massachusetts.

- The World Bank (1985). World Development Report. The World Bank, Washington, DC.

- Vu Le,Q. Zak P.(2006). "Political Risk and Capital Flight", Journal of International Money and Finance, 25, pp: 308-329.

- Yalta Y., Yalta T.(2012). "Does Financial Liberalization Decrease Capital Flight? A Panel Causality Analysis”, International Review of Economics and Finance, 22, pp:92-100. 